\title{
Alternative targets within the endocannabinoid system for future treatment of gastrointestinal diseases
}

\author{
Rudolf Schicho $\mathrm{PhD}^{1}$, Martin Storr MD²,3
}

\begin{abstract}
R Schicho, MStorr. Alternative targets within the endocannabinoid system for future treatment of gastrointestinal diseases. Can J Gastroenterol 2011;25(7):377-383.
\end{abstract}

Many beneficial effects of herbal and synthetic cannabinoids on gut motility and inflammation have been demonstrated, suggesting a vast potential for these compounds in the treatment of gastrointestinal disorders. These effects are based on the so-called 'endocannabinoid system' (ECS), a cooperating network of molecules that regulate the metabolism of the body's own and of exogenously administered cannabinoids. The ECS in the gastrointestinal tract quickly responds to homeostatic disturbances by de novo synthesis of its components to maintain homeostasis, thereby offering many potential targets for pharmacological intervention. Of major therapeutic interest are nonpsychoactive cannabinoids or compounds that do not directly target cannabinoid receptors but still possess cannabinoid-like properties. Drugs that inhibit endocannabinoid degradation and raise the level of endocannabinoids are becoming increasingly promising alternative therapeutic tools to manipulate the ECS.

Key Words: Cannabinoid receptors; Colon cancer; Emesis; Inflammatory bowel disease; Irritable bowel syndrome; Rimonabant; THC
THE ENDOCANNABINOID SYSTEM IN THE GASTROINTESTINAL TRACT

Interest in the therapeutic use of the hemp plant Cannabis sativa underwent a renaissance in the early 1960s with the discovery of delta9-tetrahydrocannabinol (THC) as the major bioactive constituent of cannabis, and in the 1990s with the description of the first cannabinoid (CB) receptor - now known as $\mathrm{CB}_{1}$. Another boost to $\mathrm{CB}$ research was the introduction of the concept of the endoCB system (ECS), which consists of the endogenously produced CBs (ie, endoCBs), their receptors ( $\mathrm{CB}$ receptors), the enzymatic machinery for the production and degradation of endoCBs, and the proteins that regulate uptake and transport of endoCBs (1) (Figure 1). In the past few years, it has become evident that the ECS plays an important role in the pathophysiology of gastrointestinal (GI) diseases and in the protection against GI inflammation (2).

\section{$\mathrm{CB}$ receptors}

In the GI tract, $\mathrm{CB}_{1}$ expression is present at prejunctional sites of cholinergic, but not nitrergic, neurons of the enteric nervous system (ENS) (3-6), in the mucosa of the stomach and the colon $(4,7,8)$, and in extrinsic fibres that originate from nodose and dorsal root ganglia (9-11). In the ENS, activated $\mathrm{CB}_{1}$ receptors inhibit the release of contractile transmitters and the downstream signalling of $\mathrm{P} 2 \mathrm{X}$ purinoceptors in cholinergic neurons, leading to relaxation of smooth muscle $(12,13)$. Therefore, $\mathrm{CB}_{1}$ appears to exert tonic control over ENS circuits, and operates as a 'brake' for neural over-reactivity (14).

Manipulation of CB receptors profoundly affects GI motility (15). In the human gut, agonists of $\mathrm{CB}_{1}$ were shown to inhibit muscle

\section{D'autres cibles dans le système endocannabinoïde pour le futur traitement des maladies gastro- intestinales}

Les nombreux effets bénéfiques des cannabinoïdes végétaux et synthétiques sur la motilité et l'inflammation intestinales sont démontrés, laissant croire au vaste potentiel de ces composés dans le traitement des troubles gastro-intestinaux. Ces effets se fondent sur le soi-disant «système endocannabinoïde » (SEC), un réseau coopératif de molécules qui régularisent le métabolisme des cannabinoïdes de l'organisme ou qui sont administrés par voie exogène. Le SEC du tube digestif réagit rapidement aux perturbations homéostatiques par synthèse de novo de ses composants pour maintenir l'homéostasie, offrant ainsi de nombreuses cibles potentielles d'intervention pharmacologique. Les cannabinoïdes, ou composants non psychoactifs, sont d'un grand intérêt thérapeutique, car ils ne ciblent pas directement les récepteurs des cannabinoïdes, mais possèdent toujours des propriétés qui y sont semblables. Les médicaments qui inhibent la dégradation endocannabinoïde et augmentent le taux d'endocannabinoïdes deviennent des outils thérapeutiques de plus en plus prometteurs pour manipuler le SEC.

contractions in the ileum and the colon $(16,17) . \mathrm{CB}_{1}$ agonists also increase food intake and inhibit vomiting, while antagonists of $\mathrm{CB}_{1}$ inhibit food intake and induce vomiting (18-21). In contrast to agonists, antagonists of $\mathrm{CB}_{1}$ increase GI motility in rodents - interestingly, diarrhea was one of the major side effects reported in clinical trials using the $\mathrm{CB}_{1}$ antagonists rimonabant and taranabant (22-24). The second $\mathrm{CB}$ receptor $\left(\mathrm{CB}_{2}\right)$ has a different distribution in the GI tract and is mainly present in immunocytes $(4,25)$, but has also been observed in colonic epithelium and ENS neurons (26,27).

\section{Novel CB receptors}

Many pharmacological effects of $\mathrm{CBs}$ cannot be explained solely by the activity of classical $\mathrm{CBs}$ (ie, $\mathrm{CB}_{1}$ and $\mathrm{CB}_{2}$ ), but rather through actions of unknown, novel $\mathrm{CB}$ receptors (28). Several G-protein coupled receptors have been suggested to function as non- $\mathrm{CB}_{1} / \mathrm{CB}_{2}$ targets (eg, GPR119 and GPR55), which are activated by the endogenous lipids oleoylethanolamide and palmitoylethanolamide, respectively (29). Another potentially novel CB receptor, GPR18, is activated by $\mathrm{N}$-arachidonoylglycine and abnormal cannabidiol (30).

EndoCBs in the GI tract: Synthesis, degradation and reuptake EndoCBs (as opposed to herbal and synthetic CBs) are produced 'on demand' from fatty acid precursors and are released into the extracellular space to bind to their respective receptors (Figure 1). The beststudied endoCBs of the bowel wall are $\mathrm{N}$-arachidonoylethanolamine (anandamide [AEA]) and 2-arachidonoylglycerol (2-AG), from which 2-AG is expressed at a higher level $(16,31)$. Both AEA and 2-AG are known to bind to $\mathrm{CB}$ receptors; however, AEA also binds to the

\footnotetext{
${ }^{1}$ Institute of Experimental and Clinical Pharmacology, Medical University of Graz, Austria; ${ }^{2}$ Division of Gastroenterology, Department of Medicine,

University of Calgary, Calgary, Alberta; ${ }^{3}$ Department of Medicine, Ludwig Maximilians University, Munich, Germany

Correspondence: Dr Martin Storr, Division of Gastroenterology, Department of Medicine, University of Calgary, 3330 Hospital Drive Northwest, Calgary, Alberta T2N 4N1. Telephone 403-210-9350,fax 403-210-9368, e-mail gidoc@gmx.com

Received for publication November 26, 2010. Accepted January 10, 2011
} 


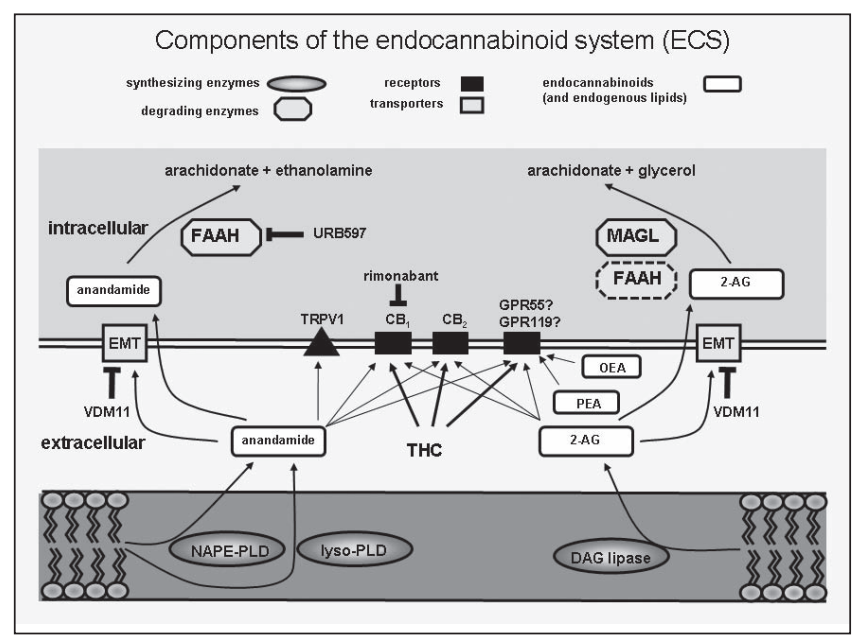

Figure 1) An overview of the endocannabinoid system and some of its inhibitors. The synthesis of endocannabinoids has several steps involving membrane phospholipids as substrates. N-acyl phosphatidylethanolamine phospholipase D (NAPE-PLD) and lysophospholipase D (lyso-PLD) catalyze the final reaction in the production of anandamide. Diacylglycerol (DAG) lipase uses diacylglycerols as substrates to produce 2-arachidonoylglycerol (2-AG). After diffusion into the extracellular space, anandamide and 2-AG bind to cannabinoid receptors 1 and $2\left(\mathrm{CB}_{1}, \mathrm{CB}_{2}\right)$, the transient receptor potential receptor vanilloid 1 receptor (TRPV1) and to the novel cannabinoid receptor GPR55 or GRP119. Actions of the endocannabinoids are terminated by cellular reuptake via an extraneuronal monoamine membrane transporter (EMT) or by passive diffusion. Anandamide is subsequently degraded by fatty acid amide hydrolase (FAAH) and 2-AG by monoacylglycerol lipase (MAGL) and FAAH, respectively. OEA Oleoylethanolamide; PEA Palmitoylethanolamide; THC Delta-9. tetrahydrocannabinol; URB597 Fatty acid amide hydrolase inhibitor; VDM11 Reuptake inhibitor

capsaicin receptor transient potential vanilloid receptor 1 (TRPV1 [formerly known as VR1]), which is an important player in gut inflammation (32). The key enzyme for the production of AEA is $\mathrm{N}$-acyl phosphatidylethanolamine phospholipase $\mathrm{D}$, while diacylglycerol lipase is responsible for the synthesis of 2-AG (Figure 1). The fatty acid amide hydrolase (FAAH) is the main enzyme for the degradation of AEA (33), but is also able to break down 2-AG (34). The principal enzyme responsible for the degradation of $2-A G$ is monoacylglycerol lipase (MAGL) and it, similar to FAAH, is expressed in enteric neurons and epithelial cells of the human and rodent GI tract $(8,10,35)$. Whether endoCBs are capable of crossing cell membranes alone or with the help of an endoCB transporter, such as the extraneuronal monoamine transporter (EMT), remains a matter of dispute.

\section{THE ECS IN GI DISEASE}

\section{$\mathrm{CB}$ receptors in $\mathrm{GI}$ disease}

$\mathrm{CB}_{2}$ receptors are not involved in the physiological regulation of GI motility; however, they appear to play a role in pathophysiological (ie, inflammatory) conditions (27). Consistent with this theory, $\mathrm{CB}_{2}$ expression is increased in colonic epithelium of patients with inflammatory bowel disease (IBD) $(4,8)$. CB receptors display a certain degree of plasticity, such that they increase their expression during GI inflammation. According to experimental models of intestinal inflammation, this increase seems to occur predominantly in myenteric plexus neurons of the ENS and in colonic epithelium $(22,25,36,37)$. However, levels of $\mathrm{CB}_{1}$ remained unaltered in patients with diverticular disease (16) and colorectal carcinoma (38), but were elevated in mucosal biopsies of duodenum from patients with active celiac disease (31). The involvement of $\mathrm{CB}_{1}$ receptors in gastric accommodation was recently reported in a human study (39) in which blockade of $\mathrm{CB}_{1}$ significantly inhibited the meal-induced gastric accommodation reflex. In the context of $\mathrm{CB}_{1}$ receptor involvement in motility, secretion, sensory function and inflammation, it seems striking that another study (40) found that a polymorphism of the $\mathrm{CB}_{1}$ receptor gene was more prevalent in a welldefined population of patients with irritable bowel syndrome (IBS) compared with healthy controls. The relevance of this observation, however, still needs to be established. Another report (41) suggested that a polymorphism in the $\mathrm{CB}_{1}$ receptor gene modulates susceptibility to ulcerative colitis and the phenotype in Crohn's disease.

\section{EndoCBs in GI disease}

Similar to CBs, endoCB levels increase during inflammation of the GI tract, and it is believed that this increase contributes to GI protection (42). Thus, AEA, but not 2-AG, was found to be elevated in ulcerative colitis patients and rodents with trinitrobenzenesulfonic acidinduced colitis (42). Levels of 2-AG increased in a mouse model of azoxymethane-induced colon cancer (43), which is consistent with previous findings in biopsies from patients with adenomatous polyposis (38). Patients with celiac disease reportedly had elevated mucosal levels of AEA and palmitoylethanolamide, which returned to normal when a gluten-free diet was initiated, suggesting a link between the pathophysiology of celiac disease and the ECS (31). Similar to other ECS components, expression and activity of FAAH and MAGL are subject to alterations during inflammation. The number of FAAHpositive cells in the colonic lamina propria was found to be higher in patients with ulcerative colitis than in healthy persons (8). The observation that blockade of FAAH with the compound URB597 attenuated experimental colitis in mice also fits well with the hypothesis that high levels of endoCBs, caused by blockade of their degrading enzyme, are protective against inflammation (44). While the presence of an EMT is still not clarified, some reports have demonstrated that the assumed EMT inhibitor VDM11 improved the severity of trinitrobenzenesulfonic acid-induced colitis $(42,44)$. Nevertheless, little is known about the role of MAGL in the GI tract, except for a study showing high expression of MAGL in immune cells and colon epithelium during human ulcerative colitis (8).

\section{TARGETS OF THE ECS IN SPECIFIC DISEASES}

\section{Nausea and vomiting}

Cannabis has been known for years to reduce emesis in patients undergoing cancer chemotherapy. This was recently evaluated in a randomized study (45) in which whole-plant cannabis led to clear improvement in chemotherapy-induced nausea and vomiting when applied in conjunction with known antiemetics. The receptors responsible for the emesis-reducing effects are $\mathrm{CB}_{1}$, TRPV1 and, most likely, $\mathrm{CB}_{2}-$ all of which are located in the brainstem $(21,46)$. Physiologically, AEA controls emesis by maintaining an endogenous tone through stimulation of $\mathrm{CB}_{1}(21)$. This suggests that high levels of AEA could be therapeutically useful to control emesis during pathophysiological states. Increased levels of AEA, for instance, can be generated by EMT blockers or by URB597, which inhibits activity of FAAH, thereby raising AEA levels (47). Because serotonin receptor antagonists or dexamethasone do not provide effective control of chemotherapy-induced emesis in patients with cancer, alternative therapies, such as $\mathrm{CBs}$, are required. The $\mathrm{CB}$ compound nabilone (Cesamet [MEDA Pharmaceuticals, USA]) has already been approved for the treatment of chemotherapy-induced nausea. According to a meta-analysis (48), nabilone and the synthetic THC product dronabinol (Marinol [Unimed pharmaceuticals Inc, USA]) were shown to be vastly superior to current antiemetic drugs such as neuroleptics. Nevertheless, the use of CBs in emesis remains unsatisfactory due to severe central side effects, such as anxiety, depression and hallucinations, that occur during treatment. Another caveat in the long-term administration of CBs may be the incidence of paroxysmal vomiting, which has been noted in patients with a history of chronic cannabis use (49). 


\section{Gastroesophageal reflux disease and gastric ulcer}

Transient lower esophageal sphincter relaxation is caused by a derangement of the sphincter mechanism and underlies the symptoms of gastroesophageal reflux disease in a significant proportion of patients. THC inhibited the increase in meal-induced transient lower esophageal sphincter relaxation and reduced lower esophageal sphincter pressure in humans (50), confirming the results of $\mathrm{CB}_{1}$ agonist studies in animals (51).

\section{IBS}

Almost $20 \%$ of adults in western countries suffer from IBS, which is a functional GI disorder characterized by abdominal discomfort, bloating, altered bowel habits and the absence of organic abnormalities (52). Its etiology is complex, because it incorporates biological and psychosocial factors. There is principle agreement that alterations in gut motility, disturbances in gut-brain signalling, visceral hypersensitivity and bacterial overgrowth contribute to its pathophysiology (53). A recent study in the Korean population (40) suggested that a polymorphism of the CNR1 gene (which encodes the $\mathrm{CB}_{1}$ receptor) could also play a role in the development of IBS. In addition, an FAAH gene polymorphism (C385A) has been associated with accelerated colonic transit in patients with diarrhea-predominant IBS (D-IBS) and mixed-form IBS (54).

Gut motility and processing of visceral pain within the central nervous system have been extensively investigated in IBS (55). Thus, the occurrence of disturbed phasic contractions of the colon after a meal is typical of IBS patients, ie, colonic transit time is accelerated in D-IBS whereas transit is slower in constipation-predominant IBS (C-IBS) $(56,57)$. Based on the fact that CBs are major relaxant drugs of GI motility and, that peristalsis is under tonic control of $\mathrm{CB}_{1}(58)$, $\mathrm{CB}_{1}$ agonists could treat D-IBS diarrhea while $\mathrm{CB}_{1}$ antagonists could be valuable for the treatment of constipation in C-IBS and of dyspepsia, which frequently overlaps with IBS (59). Despite the absence of organic abnormalities, certain aspects of inflammation are involved in IBS. Elevated levels of the proinflammatory cytokines interleukin (IL)- 6 and IL- 8 have been detected in the plasma of IBS patients, while those with comorbidities had elevated levels of tumour necrosis factoralpha and IL-1-beta in addition to IL-6 and IL-8 (60). Furthermore, an epidemiological study (61) revealed a large overlap of patients with microscopic colitis and IBS symptoms. In view of these observations, it would be worthwhile to target CBs during IBS treatment.

It is assumed that exaggerated visceral sensation generated either by central and/or peripheral mechanisms underlie the symptoms of abdominal pain in IBS (62). CBs have been demonstrated to provide analgesia, possibly indicating involvement of the ECS in visceral sensation (63). A very recent study (64), however, indicated that visceral sensitivity to rectal distension was unaffected by THC administration to IBS patients and healthy individuals, arguing against the possibility of using $\mathrm{CB}$ agonists to treat visceral hypersensitivity.

TRPV1, which is activated by the endoCB AEA, has been implicated in visceral hypersensitivity to colon distension in rodents (65). This finding is of importance for the human gut, which shows an increased density of TRPV1-immunoreactive fibres in patients with IBS (66). Pharmacological manipulation of TRPV1 may be superior to that of $\mathrm{CB}_{1}$, partly because of the aforementioned reason but also because of the observation that rats treated with the $\mathrm{CB}_{1}$ antagonist rimonabant develop hypoalgesia during repeated colorectal distension - a phenomenon that has not been observed with TRPV1 antagonists (67). In this context, the use of FAAH blockers that raise AEA levels - but also act as TRPV1 antagonists - could be an interesting option for the treatment of visceral hypersensitivity.

\section{IBD}

IBD is a chronic and relapsing inflammation of the GI tract, and comprises two clinical forms: Crohn's disease and ulcerative colitis. The etiology of IBD remains unresolved, although it is commonly agreed that it is a multifactorial disease caused by an uncontrolled immune response to microbial antigens (68). There are anecdotal reports (69) that people with IBD experience relief when smoking marijuana, suggesting a protective role for $\mathrm{CB}$ receptors and the ECS in intestinal inflammation. An anti-inflammatory role for $\mathrm{CB}$ receptors has been demonstrated in several studies of chemically induced colitis in mice $(25,36,70)$ - the ECS may, therefore, play a protective role in IBD (ie, that upregulation of ECS components could positively influence disease progression) (42). Evaluation of colonic biopsies from patients with ulcerative colitis revealed high levels of AEA (42), a large influx of $\mathrm{CB}_{2}$-positive cells $(4,8)$ and an increased expression of MAGL and diacylglycerol lipase in the colonic epithelium (8). The exact mechanisms by which CB receptors and other ECS components confer protection during colitis has not been determined. Because $\mathrm{CB}_{1}$ receptor activity promotes the reconstitution of injured colonic epithelium (4), it is possible that $\mathrm{CBs}$ accelerate wound closure during colitis, although an inhibitory effect on the release of proinflammatory cytokines is also conceivable (71).

Genetic susceptibility is a major etiological factor in the development of IBD. Accordingly, polymorphisms in the FAAH and CNR1 genes have been investigated in human IBD. A FAAH gene polymorphism has been detected in patients with D-IBS (54), but not in Crohn's disease (44). A CNR1 gene polymorphism (CNR1 p.Thr453Thr) may be associated with genetic susceptibility in ulcerative colitis and phenotypic changes in Crohn's disease (41). Collectively, results from animal and human studies strongly suggest that pharmacological manipulation of the ECS could be of great therapeutic value in patients with IBD.

\section{Colon cancer}

CBs have shifted into the field of cancer research mainly because of their ability to reduce proliferation and induce apoptosis of tumour cells, suggesting a protective role for the ECS in colon cancer patients (38). In colorectal tumour cells, apoptotic and antiproliferative effects are mediated by $\mathrm{CB}_{1}$; however, $\mathrm{CB}_{2}$ receptors may also be involved depending on the cell line tested $(38,72)$. AEA has been shown to inhibit migration of colon carcinoma cells via $\mathrm{CB}_{1}$, and to cause nonapoptotic and non-necrotic cell death in apoptosis-resistant colon cancer cells that depend on the presence of cyclooxegenase-2 (73). Because colorectal tumour cells express high levels of cyclooxegenase-2 (which is known to promote tumourigenesis), AEA could be a valuable therapeutic tool against colon tumours resistant to apoptosis (73). In HT-29 and DLD-1 cells, $\mathrm{CB}_{1}$ and $\mathrm{CB}_{2}$ activation caused apoptosis via TNF-alpha-sensitive ceramide synthesis (74). Similar to GI inflammation, changes in the levels of ECS components also occur during the development of colon cancer: levels of AEA and 2-AG were increased in colorectal adenomas and adenocarcinomas compared with normal mucosa (31). The $\mathrm{CB}_{1}$ receptor may provide the strongest link to colon cancer because $\mathrm{CB}_{1}$, but not $\mathrm{CB}_{2}$, was shown to be downregulated in colon carcinoma (75), indicating that absence of the $\mathrm{CB}_{1}$ receptor promotes tumourigenesis. It should be mentioned that a different study (38) failed to observe a downregulation of $\mathrm{CB}_{1}$ in colonic biopsies of patients with colorectal cancer. Other ECS components, such as FAAH, may also play a role in tumourigenesis, probably via the increase of endoCB levels. For example, in a mouse model of azoxymethane-induced carcinogenesis (43), the FAAH inhibitor $\mathrm{N}$-arachidonoylserotonin reduced aberrant crypt foci (early neoplastic lesions) in the colon and increased 2-AG levels. In the APC gene knock-out model (75), mice with an additional deletion in the CNR1 gene or that were subjected to pharmacological blockade of the $\mathrm{CB}_{1}$ receptor, demonstrated a higher colonic tumour burden than their littermates. The authors also demonstrated an increase in DNA methylation of the CNR1 promoter, indicating that epigenetic silencing of the CNR1 gene may have been responsible for the enhanced growth of tumours. In contrast to these findings, the $\mathrm{CB}_{1}$ antagonist rimonabant inhibited the growth of cancer cells and the development of precancerous lesions in mice (76).

Collectively, the ECS fundamentally affects colon tumourigenesis. Targeting the $\mathrm{CB}_{1}$ receptor or the FAAH enzyme (to raise endoCB levels) could be helpful in the protection against colorectal cancer. 
TABLE 1

Potential therapeutic effects of drugs targeting the endocannabinoid system in gastrointestinal (GI) diseases

\begin{tabular}{|c|c|c|c|c|c|c|}
\hline \multirow[b]{2}{*}{ Condition } & \multicolumn{2}{|c|}{ Agonists } & \multicolumn{2}{|c|}{ Antagonists } & \multirow[b]{2}{*}{ FAAH blockers } & \multirow[b]{2}{*}{$\begin{array}{l}\text { Reuptake } \\
\text { inhibitors }\end{array}$} \\
\hline & $\begin{array}{l}\text { Cannabinoid } \\
\text { receptor } 1\end{array}$ & $\begin{array}{l}\text { Cannabinoid } \\
\text { receptor } 2\end{array}$ & $\begin{array}{l}\text { Cannabinoid } \\
\text { receptor } 1\end{array}$ & $\begin{array}{l}\text { Cannabinoid } \\
\text { receptor } 2\end{array}$ & & \\
\hline Emesis & $\begin{array}{l}\text { Reduction of emesis } \\
(18,83)\end{array}$ & Inhibition of emesis (46) & & & $\begin{array}{l}\text { Inhibition of toxin- } \\
\text { induced vomiting } \\
\text { (82) }\end{array}$ & $\begin{array}{l}\text { Inhibition of } \\
\text { apomorphin- } \\
\text { induced emesis } \\
\text { (84) }\end{array}$ \\
\hline
\end{tabular}

IBS Reduction of visceral pain Reduction of visceral

$\begin{array}{ll}(63), \text { secretion }(5,85), & \text { hypersensitivity (79), } \\ \text { hypermotility and diarrhea } & \text { secretion (85) and } \\ (22,86) & \text { hypermotility (27) }\end{array}$

Reduction of intestinal Reduction of inflammation
inflammation, visceral pain, and visceral
hypermotility and diarrhea hypersensitivity $(4,25,70)$
$(22,36,63)$

lleus $(22,36,63)$

\begin{tabular}{|c|c|c|}
\hline GERD & Reduction of TLESR (50) & \\
\hline \multicolumn{3}{|c|}{ Constipation } \\
\hline Diarrhea & $\begin{array}{l}\text { Reduction of intestinal } \\
\text { transit and hypermotility } \\
(22)\end{array}$ & $\begin{array}{l}\text { Reduction of hypermotility } \\
\text { (89) }\end{array}$ \\
\hline
\end{tabular}

Increase in GI transit Increase in GI transit in in paralytic and septic ileus (87) septic ileus $(37,87)$

$\begin{array}{ll}\begin{array}{l}\text { Reduction of GI } \\ \text { inflammation }\end{array} & \begin{array}{c}\text { Reduction of } \mathrm{Gl} \\ \text { inflammation }\end{array} \\ (36,44) & (42,44)\end{array}$

Increase in GI transit

(88)

Gastroparesis (22) (89)

$\begin{array}{ll}\begin{array}{l}\text { Reduction of } \\ \text { intestinal transit }\end{array} & \begin{array}{l}\text { Reduction of } \\ \text { intestinal transit }\end{array} \\ (90) & (91)\end{array}$

Increase in gastric emptying (92)

Numbers in parentheses indicate reference(s). FAAH Fatty acid amide hydrolase; GERD Gastroesophageal reflux disease; IBD Inflammatory bowel disease; IBS Irritable bowel syndrome; TLESR Transient lower esophageal sphincter relaxation

\section{CURRENTLY AVAILABLE CBs FOR CLINICAL USE}

Several CBs have already been marketed and are prescribed in certain countries. A combination of THC and cannabidiol is available in Canada under the brand name Sativex (GW Pharmaceuticals, United Kingdom), which is provided as a sublingual oromucosal spray, and prescribed for pain and spasticity in patients with multiple sclerosis. Dronabinol (Marinol [Abbott Laboratories Inc, Canada]) is a synthetic THC that functions as an agonist for both $\mathrm{CB}_{1}$ and $\mathrm{CB}_{2}$. It has been marketed as an appetite stimulant and antiemetic, and is taken orally as a capsule. Nabilone is a synthetic THC analogue that is marketed under the brand name Cesamet (Valeant Pharmaceuticals, Canada]). It is used for treating patients with chemotherapy-induced nausea and vomiting, and taken orally as a capsule.

\section{POSSIBLE TARGETS AND EXPERIMENTAL DRUGS}

Apart from the classical CB receptors, the ECS may hold additional CB-responsive drug targets for GI disease (eg, novel CB receptors such as GPR55, GPR119 and GPR18). CBs acting via these non- $\mathrm{CB}_{1} / \mathrm{CB}_{2}$ sites could become promising therapeutic tools in the future. The phytoCBs cannabidiol and delta 9-tetrahydrocannabivarin have no or only weak affinity for $\mathrm{CB}$ receptors, but may have large potential in the treatment and cure of GI diseases. In rodents, cannabidiol improved experimental colitis $(77,78)$ and reduced hypermotility in ileitis (79), while delta 9-tetrahydrocannabivarin reduced food intake and body weight (80). Recently, it was demonstrated that the atypical CB compound O-1602 protected against experimental colitis by a mechanism that involved inhibition of neutrophil recruitment to the site of inflammation (81). The authors showed that the beneficial effect of O-1602 did not involve $\mathrm{CB}_{1}, \mathrm{CB}_{2}$ or the novel $\mathrm{CB}$ receptor GPR55, suggesting that an unknown non- $\mathrm{CB}_{1} / \mathrm{CB}_{2}$ target could have mediated the protective mechanism. An important approach to the pharmacological exploitation of the ECS was initiated by the blockade of FAAH activity. The desired effect is an increase in endoCB levels that drives $\mathrm{CB}$ activity and provides protection against inflammation.
This approach has proven to be very effective in animal models of emesis (82), colitis $(36,42,44)$ and colon cancer (43). The same desired effect has been achieved in a mouse model of experimental colitis by application of the EMT blocker VDM11 (44). Table 1 summarizes the targets and potential beneficial effects of $\mathrm{CB}$ drugs in various GI diseases.

\section{SUMMARY AND FUTURE DIRECTIONS}

Extracts from Cannabis sativa have been used in traditional medicine to treat inflammation and diarrhea. AEA and 2-AG represent the best-studied endoCBs and act via classical $\left(\mathrm{CB}_{1}\right.$ and $\left.\mathrm{CB}_{2}\right)$ and, probably, via novel CB receptors such as GPR55, GPR119 or GPR18. EndoCBs and $\mathrm{CB}$ receptors are integrated in the ECS, which displays a high degree of plasticity in GI diseases with the aim of protecting GI homeostasis. The fact that cells produce their own CBs offers a unique opportunity for future drug targeting - either to manipulate endoCB receptors, or to inhibit the degradation of endoCBs to increase their levels in the extracellular space. Available studies suggest that $\mathrm{CB}_{1}$ agonists may be useful in emesis, IBD, colon cancer and functional disorders associated with hypermotility and diarrhea, while $\mathrm{CB}_{2}$ agonists may be future drugs used for the treatment of IBD. Additionally, there are strong arguments supporting the use of CBs for the treament of IBS.

Pharmacological manipulation of the ECS, however, has its problems and caveats. The $\mathrm{CB}_{1}$ antagonist rimonabant (Acomplia [SanofiAventis, United Kingdom]) had already been introduced as an anti-obesity drug, but was withdrawn from the market due to its serious psychoactive side effects including sedation, drowsiness, depression and paranoia. This exemplifies the primary obstacle to the pharmacological exploitation of $\mathrm{CB}_{1}$ ligands: unwanted central effects that are only overcome if $\mathrm{CB}_{1}$ ligands are prevented from crossing the blood-brain barrier, or if they are chemically modified such that their psychoactive effects are mitigated. It is not certain whether ligands remain fully effective if their actions are restricted only to peripheral $\mathrm{CB}$ receptors. The generation of $\mathrm{CB}_{1}$ ligands that predominantly act at peripheral sites will be an 
important step toward the clinical use of these drugs. Because expression of $\mathrm{CB}_{2}$ in the central nervous system is low, targeting of $\mathrm{CB}_{2}$ receptors will be less of a problem. The absence of unwanted psychoactivity suggests that $\mathrm{CB}_{2}$ agonists may be useful drugs for GI inflammation. The discovery of novel $\mathrm{CB}$ receptors and proteins that regulate endoCB metabolism will expand the definition of the ECS and will offer new therapeutic targets to reduce the problem of unwanted psychoactive effects associated with CB treatment.

ACKNOWLEDGEMENTS: RS is supported by the Austrian Science Fund (FWF grant P22771-B18) and the F Lanyar Foundation. Work in the laboratory of MS is supported by the Crohn's and Colitis Foundation of Canada.

\section{REFERENCES}

1. De Petrocellis L, Di Marzo V. An introduction to the endocannabinoid system: From the early to the latest concepts. Best Pract Res Clin Endocrinol Metab 2009;23:1-15.

2. Izzo AA, Camilleri M. Emerging role of cannabinoids in gastrointestinal and liver diseases: Basic and clinical aspects. Gut 2008;57:1140-55.

3. Coutts AA, Irving AJ, Mackie K, Pertwee RG, Anavi-Goffer S. Localisation of cannabinoid $\mathrm{CB}_{1}$ receptor immunoreactivity in the guinea pig and rat myenteric plexus. J Comp Neurol 2002;448:410-22.

4. Wright K, Rooney N, Feeney M, et al. Differential expression of cannabinoid receptors in the human colon: Cannabinoids promote epithelial wound healing. Gastroenterology 2005;129:437-53.

5. MacNaughton WK, Van Sickle MD, Keenan CM, Cushing K, Mackie K, Sharkey KA. Distribution and function of the cannabinoid-1 receptor in the modulation of ion transport in the guinea pig ileum: Relationship to capsaicin-sensitive nerves. Am J Physiol Gastrointest Liver Physiol 2004;286:G863-71.

6. Storr M, Sibaev A, Marsicano G, et al. Cannabinoid receptor type 1 modulates excitatory and inhibitory neurotransmission in mouse colon. Am J Physiol Gastrointest Liver Physiol 2004;286:G110-7.

7. Pazos MR, Tolon RM, Benito $\mathrm{C}$, et al. Cannabinoid $\mathrm{CB}_{1}$ receptors are expressed by parietal cells of the human gastric mucosa. J Histochem Cytochem 2008;56:511-6.

8. Marquéz L, Suárez J, Iglesias M, Bermudez-Silva FJ, Rodríguez de FF, Andreu M. Ulcerative colitis induces changes on the expression of the endocannabinoid system in the human colonic tissue. PLoS One 2009;4:e6893.

9. Hohmann AG, Herkenham M. Localization of central cannabinoid $\mathrm{CB}_{1}$ receptor messenger RNA in neuronal subpopulations of rat dorsal root ganglia: A double-label in situ hybridization study. Neuroscience 1999;90:923-31.

10. Bridges D, Rice AS, Egertova M, Elphick MR, Winter J, Michael GJ. Localisation of cannabinoid receptor 1 in rat dorsal root ganglion using in situ hybridisation and immunohistochemistry. Neuroscience 2003;119:803-12.

11. Burdyga G, Lal S, Varro A, Dimaline R, Thompson DG, Dockray GJ. Expression of cannabinoid $\mathrm{CB}_{1}$ receptors by vagal afferent neurons is inhibited by cholecystokinin. J Neurosci 2004;24:2708-15.

12. Pertwee RG. Cannabinoids and the gastrointestinal tract. Gut 2001;48:859-67.

13. Baldassano $\mathrm{S}, \mathrm{Zizzo} \mathrm{MG}$, Serio R, Mulè F. Interaction between cannabinoid $\mathrm{CB}_{1}$ receptors and endogenous ATP in the control of spontaneous mechanical activity in mouse ileum. Br J Pharmacol 2009;158:243-51.

14. Boesmans W, Ameloot K, Van den Abbeel V, Tack J, Vanden Berghe P. Cannabinoid receptor 1 signalling dampens activity and mitochondrial transport in networks of enteric neurones. Neurogastroenterol Motil 2009;21:958-e77.

15. Fioramonti J, Bueno L. Role of cannabinoid receptors in the control of gastrointestinal motility and perception. Expert Rev Gastroenterol Hepatol 2008;2:385-97.

16. Guagnini F, Valenti M, Mukenge S, et al. Neural contractions in colonic strips from patients with diverticular disease: Role of endocannabinoids and substance P. Gut 2006;55:946-53.

17. Manara L, Croci T, Guagnini F, et al. Functional assessment of neuronal cannabinoid receptors in the muscular layers of human ileum and colon. Dig Liver Dis 2002;34:262-9.
18. Van Sickle MD, Oland LD, Ho W, et al. Cannabinoids inhibit emesis through $\mathrm{CB}_{1}$ receptors in the brainstem of the ferret. Gastroenterology 2001;121:767-74.

19. Darmani NA. The cannabinoid $\mathrm{CB}_{1}$ receptor antagonist SR 141716A reverses the antiemetic and motor depressant actions of WIN 55, 212-2. Eur J Pharmacol 2001;430:49-58.

20. Darmani NA, Johnson JC. Central and peripheral mechanisms contribute to the antiemetic actions of delta-9-tetrahydrocannabinol against 5-hydroxytryptophan-induced emesis. Eur J Pharmacol 2004:488:201-12.

21. Sharkey KA, Cristino L, Oland LD, et al. Arvanil, anandamide and $\mathrm{N}$-arachidonoyl-dopamine (NADA) inhibit emesis through cannabinoid $\mathrm{CB}_{1}$ and vanilloid TRPV1 receptors in the ferret. Eur J Neurosci 2007;25:2773-82.

22. Izzo AA, Fezza F, Capasso R, et al. Cannabinoid $\mathrm{CB}_{1}$-receptor mediated regulation of gastrointestinal motility in mice in a model of intestinal inflammation. Br J Pharmacol 2001;134:563-70.

23. Ruilope LM, Després JP, Scheen A, et al. Effect of rimonabant on blood pressure in overweight/obese patients with/without co-morbidities: Analysis of pooled RIO study results. J Hypertens 2008;26:357-67.

24. Kipnes MS, Hollander P, Fujioka K, et al. A one-year study to assess the safety and efficacy of the $\mathrm{CB}_{1} \mathrm{R}$ inverse agonist taranabant in overweight and obese patients with type 2 diabetes. Diabetes Obes Metab 2010;12:517-31.

25. Kimball ES, Schneider CR, Wallace NH, Hornby PJ. Agonists of cannabinoid receptor 1 and 2 inhibit experimental colitis induced by oil of mustard and by dextran sulfate sodium. Am J Physiol Gastrointest Liver Physiol 2006;291:G364-71.

26. Wright KL, Duncan M, Sharkey KA. Cannabinoid $\mathrm{CB}_{2}$ receptors in the gastrointestinal tract: A regulatory system in states of inflammation. Br J Pharmacol 2008;153:263-70.

27. Duncan M, Mouihate A, Mackie K, et al. Cannabinoid $\mathrm{CB}_{2}$ receptors in the enteric nervous system modulate gastrointestinal contractility in lipopolysaccharide-treated rats. Am J Physiol Gastrointest Liver Physiol 2008;295:G78-87.

28. Kreitzer FR, Stella N. The therapeutic potential of novel cannabinoid receptors. Pharmacol Ther 2009;122:83-96.

29. Godlewski G, Offertáler L, Wagner JA, Kunos G. Receptors for acylethanolamides-GPR55 and GPR119. Prostaglandins Other Lipid Mediat 2009;89:105-11.

30. McHugh D, Hu SS, Rimmerman N, et al. N-arachidonoyl glycine, an abundant endogenous lipid, potently drives directed cellular migration through GPR18, the putative abnormal cannabidiol receptor. BMC Neurosci 2010;11:44.

31. D'Argenio G, Petrosino S, Gianfrani C, et al. Overactivity of the intestinal endocannabinoid system in celiac disease and in methotrexate-treated rats. J Mol Med 2007;85:523-30.

32. Kimball ES, Wallace NH, Schneider CR, D'Andrea MR, Hornby PJ. Vanilloid receptor 1 antagonists attenuate disease severity in dextran sulphate sodium-induced colitis in mice. Neurogastroenterol Motil 2004;16:811-8.

33. Cravatt BF, Lichtman AH. The enzymatic inactivation of the fatty acid amide class of signaling lipids. Chem Phys Lipids 2002;121:135-48.

34. Goparaju SK, Ueda N, Yamaguchi H, Yamamoto S. Anandamide amidohydrolase reacting with 2-arachidonoylglycerol, another cannabinoid receptor ligand. FEBS Lett 1998;422:69-73.

35. Duncan M, Thomas AD, Cluny NL, et al. Distribution and function of monoacylglycerol lipase in the gastrointestinal tract. Am J Physiol Gastrointest Liver Physiol 2008;295:G1255-65.

36. Massa F, Marsicano G, Hermann H, et al. The endogenous cannabinoid system protects against colonic inflammation. J Clin Invest 2004;113:1202-9.

37. Mascolo N, Izzo AA, Ligresti A, et al. The endocannabinoid system and the molecular basis of paralytic ileus in mice. FASEB J 2002;16:1973-5.

38. Ligresti A, Bisogno T, Matias I, et al. Possible endocannabinoid control of colorectal cancer growth. Gastroenterology 2003;125:677-87.

39. Ameloot K, Janssen P, Scarpellini E, et al. Endocannabinoid control of gastric sensorimotor function in man. Aliment Pharmacol Ther 2010;31:1123-31.

40. Park JM, Choi MG, Cho YK, et al. Cannabinoid receptor 1 gene polymorphism and irritable bowel syndrome in the Korean population: A hypothesis-generating study. J Clin Gastroenterol 2011;45:45-9. 
41. Storr M, Emmerdinger D, Diegelmann J, et al. The cannabinoid 1 receptor (CNR1) 1359 G/A polymorphism modulates susceptibility to ulcerative colitis and the phenotype in Crohn's disease. PLoS One 2010;5:e9453.

42. D’Argenio G, Valenti M, Scaglione G, Cosenza V, Sorrentini I, Di Marzo V. Up-regulation of anandamide levels as an endogenous mechanism and a pharmacological strategy to limit colon inflammation. FASEB J 2006;20:568-70.

43. Izzo AA, Aviello G, Petrosino S, et al. Increased endocannabinoid levels reduce the development of precancerous lesions in the mouse colon. J Mol Med 2008;86:89-98.

44. Storr MA, Keenan CM, Emmerdinger D, et al. Targeting endocannabinoid degradation protects against experimental colitis in mice: Involvement of $\mathrm{CB}_{1}$ and $\mathrm{CB}_{2}$ receptors. J Mol Med 2008;86:925-36.

45. Duran M, Pérez E, Abanades S, et al. Preliminary efficacy and safety of an oromucosal standardized cannabis extract in chemotherapyinduced nausea and vomiting. Br J Clin Pharmacol 2010;70:656-63.

46. Van Sickle MD, Duncan M, Kingsley PJ, et al. Identification and functional characterization of brainstem cannabinoid $\mathrm{CB}_{2}$ receptors. Science 2005;310:329-32.

47. Fegley D, Gaetani S, Duranti A, et al. Characterization of the fatty acid amide hydrolase inhibitor cyclohexyl carbamic acid 3'-carbamoyl-biphenyl-3-yl ester (URB597): Effects on anandamide and oleoylethanolamide deactivation. J Pharmacol Exp Ther 2005;313:352-8.

48. Machado Rocha FC, Stéfano SC, De Cássia Haiek R, Rosa Oliveira LM, Da Silveira DX. Therapeutic use of Cannabis sativa on chemotherapy-induced nausea and vomiting among cancer patients: Systematic review and meta-analysis. Eur J Cancer Care 2008;17:431-43.

49. Chepyala P, Olden KW. Cyclic vomiting and compulsive bathing with chronic cannabis abuse. Clin Gastroenterol Hepatol 2008;6:710-2.

50. Beaumont H, Jensen J, Carlsson A, Ruth M, Lehmann A, Boeckxstaens G. Effect of delta 9-tetrahydrocannabinol, a cannabinoid receptor agonist, on the triggering of transient lower oesophageal sphincter relaxations in dogs and humans. Br J Pharmacol 2009;156:153-62.

51. Lehmann A, Blackshaw LA, Branden L, et al. Cannabinoid receptor agonism inhibits transient lower esophageal sphincter relaxations and reflux in dogs. Gastroenterology 2002;123:1129-34.

52. Longstreth GF, Thompson WG, Chey WD, Houghton LA, Mearin F, Spiller RC. Functional bowel disorders. Gastroenterology 2006;130:1480-91.

53. Drossman DA. The functional gastrointestinal disorders and the Rome III process. Gastroenterology 2006;130:1377-90.

54. Camilleri M, Carlson P, McKinzie S, et al. Genetic variation in endocannabinoid metabolism, gastrointestinal motility, and sensation. Am J Physiol Gastrointest Liver Physiol 2008;294:G13-9.

55. Spiller R, Aziz Q, Creed F, et al. Guidelines on the irritable bowel syndrome: Mechanisms and practical management. Gut 2007;56:1770-98.

56. Chey WY, Jin HO, Lee MH, Sun SW, Lee KY. Colonic motility abnormality in patients with irritable bowel syndrome exhibiting abdominal pain and diarrhea. Am J Gastroenterol 2001;96:1499-506.

57. Bassotti G, Chistolini F, Marinozzi G, Morelli A. Abnormal colonic propagated activity in patients with slow transit constipation and constipation-predominant irritable bowel syndrome. Digestion 2003;68:178-83.

58. Grider JR, Mahavadi S, Li Y, et al. Modulation of motor and sensory pathways of the peristaltic reflex by cannabinoids. Am J Physiol Gastrointest Liver Physiol 2009;297:G539-49.

59. Wang A, Liao X, Xiong L, et al. The clinical overlap between functional dyspepsia and irritable bowel syndrome based on Rome III criteria. BMC Gastroenterol 2008;8:43.

60. Scully P, McKernan DP, Keohane J, et al. Plasma cytokine profiles in females with irritable bowel syndrome and extra-intestinal co-morbidity. Am J Gastroenterol 2010;105:2235-43.

61. Limsui D, Pardi DS, Camilleri M, et al. Symptomatic overlap between irritable bowel syndrome and microscopic colitis. Inflamm Bowel Dis 2007;13:175-81.

62. Azpiroz F, Bouin M, Camilleri M, et al. Mechanisms of hypersensitivity in IBS and functional disorders. Neurogastroenterol Motil 2007;19(Suppl 1):62-88.
63. Sanson M, Bueno L, Fioramonti J. Involvement of cannabinoid receptors in inflammatory hypersensitivity to colonic distension in rats. Neurogastroenterol Motil 2006;18:949-56.

64. Klooker TK, Leliefeld KE, van den Wijngaard RM, Boeckxstaens GE. The cannabinoid receptor agonist delta-9-tetrahydrocannabinol does not affect visceral sensitivity to rectal distension in healthy volunteers and IBS patients. Neurogastroenterol Motil 2011;23:30-5,e2.

65. Miranda A, Nordstrom E, Mannem A, Smith C, Banerjee B, Sengupta JN. The role of transient receptor potential vanilloid 1 in mechanical and chemical visceral hyperalgesia following experimental colitis. Neuroscience 2007;148:1021-32.

66. Akbar A, Yiangou Y, Facer P, Walters JR, Anand P, Ghosh S. Increased capsaicin receptor TRPV1-expressing sensory fibres in irritable bowel syndrome and their correlation with abdominal pain. Gut 2008;57:923-9.

67. Ravnefjord A, Brusberg M, Kang D, et al. Involvement of the transient receptor potential vanilloid 1 (TRPV1) in the development of acute visceral hyperalgesia during colorectal distension in rats. Eur J Pharmacol 2009;611:85-91.

68. Strober W, Fuss I, Mannon P. The fundamental basis of inflammatory bowel disease. J Clin Invest 2007;117:514-21.

69. Izzo AA, Camilleri M. Cannabinoids in intestinal inflammation and cancer. Pharmacol Res 2009;60:117-25.

70. Storr MA, Keenan CM, Zhang H, Patel KD, Makriyannis A, Sharkey KA. Activation of the cannabinoid 2 receptor $\left(\mathrm{CB}_{2}\right)$ protects against experimental colitis. Inflamm Bowel Dis 2009; 15:1678-85.

71. Ihenetu K, Molleman A, Parsons ME, Whelan CJ. Inhibition of interleukin-8 release in the human colonic epithelial cell line HT-29 by cannabinoids. Eur J Pharmacol 2003;458:207-15.

72. Greenhough A, Patsos HA, Williams AC, Paraskeva C. The cannabinoid $\Delta 9$-tetrahydrocannabinol inhibits RAS-MAPK and PI3K-AKT survival signalling and induces BAD-mediated apoptosis in colorectal cancer cells. Int J Cancer 2007;121:2172-80.

73. Patsos HA, Hicks DJ, Dobson RR, et al. The endogenous cannabinoid, anandamide, induces cell death in colorectal carcinoma cells: A possible role for cyclooxygenase 2 . Gut 2005;54:1741-50.

74. Cianchi F, Papucci L, Schiavone N, et al. Cannabinoid receptor activation induces apoptosis through tumor necrosis factor alpha-mediated ceramide de novo synthesis in colon cancer cells. Clin Cancer Res 2008;14:7691-700.

75. Wang D, Wang H, Ning W, Backlund MG, Dey SK, DuBois RN. Loss of cannabinoid receptor 1 accelerates intestinal tumor growth. Cancer Res 2008;68:6468-76.

76. Santoro A, Pisanti S, Grimaldi C, et al. Rimonabant inhibits human colon cancer cell growth and reduces the formation of precancerous lesions in the mouse colon. Int J Cancer 2009;125:996-1003.

77. Borrelli F, Aviello G, Romano B, et al. Cannabidiol, a safe and non-psychotropic ingredient of the marijuana plant Cannabis sativa, is protective in a murine model of colitis. J Mol Med 2009;87:1111-21.

78. Jamontt JM, Molleman A, Pertwee RG, Parsons ME. The effects of $\Delta 9$-tetrahydrocannabinol and cannabidiol alone and in combination on damage, inflammation and in vitro motility disturbances in rat colitis. Br J Pharmacol 2010;160:712-23.

79. Capasso R, Borrelli F, Aviello G, et al. Cannabidiol, extracted from Cannabis sativa, selectively inhibits inflammatory hypermotility in mice. Br J Pharmacol 2008;154:1001-8.

80. Riedel G, Fadda P, Killop-Smith S, Pertwee RG, Platt B, Robinson L. Synthetic and plant-derived cannabinoid receptor antagonists show hypophagic properties in fasted and non-fasted mice. Br J Pharmacol 2009;156:1154-66.

81. Schicho R, Bashashati M, Bawa M, et al. The atypical cannabinoid O-1602 protects against experimental colitis and inhibits neutrophil recruitment. Inflamm Bowel Dis 2010 (DOI: 10.1002/ibd.21583).

82. Parker LA, Limebeer CL, Rock EM, Litt DL, Kwiatkowska M, Piomelli D. The FAAH inhibitor URB-597 interferes with cisplatin- and nicotine-induced vomiting in the Suncus murinus (house musk shrew). Physiol Behav 2009;97:121-4

83. Tramer MR, Carroll D, Campbell FA, Reynolds DJ, Moore RA, McQuay HJ. Cannabinoids for control of chemotherapy induced nausea and vomiting: Quantitative systematic review. BMJ 2001;323:16-21.

84. Darmani NA, McClanahan BA, Trinh C, Petrosino S, Valenti M, Di Marzo V. Cisplatin increases brain 2-arachidonoylglycerol 
(2-AG) and concomitantly reduces intestinal 2-AG and anandamide levels in the least shrew. Neuropharmacology 2005;49:502-13.

85. Fichna J, Schicho R, Andrews CN, et al. Salvinorin A inhibits colonic transit and neurogenic ion transport in mice by activating kappa-opioid and cannabinoid receptors. Neurogastroenterol Motil 2009;21:1326-e128.

86. Izzo AA, Capasso F, Costagliola A, et al. An endogenous cannabinoid tone attenuates cholera toxin-induced fluid accumulation in mice. Gastroenterology 2003;125:765-74.

87. $\mathrm{Li} \mathrm{YY,} \mathrm{Li} \mathrm{YN,} \mathrm{Ni} \mathrm{JB,} \mathrm{et} \mathrm{al.} \mathrm{Involvement} \mathrm{of} \mathrm{cannabinoid-1} \mathrm{and}$ cannabinoid-2 receptors in septic ileus. Neurogastroenterol Motil 2010;22:350-e88.

88. Yuece B, Sibaev A, Broedl UC, et al. Cannabinoid type 1 receptor modulates intestinal propulsion by an attenuation of intestinal motor responses within the myenteric part of the peristaltic reflex. Neurogastroenterol Motil 2007;19:744-53.

89. Mathison R, Ho W, Pittman QJ, Davison JS, Sharkey KA. Effects of cannabinoid receptor-2 activation on accelerated gastrointestinal transit in lipopolysaccharide-treated rats. Br J Pharmacol 2004;142:1247-54.

90. Capasso R, Matias I, Lutz B, et al. Fatty acid amide hydrolase controls mouse intestinal motility in vivo. Gastroenterology 2005;129:941-51

91. Pinto L, Izzo AA, Cascio MG, et al. Endocannabinoids as physiological regulators of colonic propulsion in mice. Gastroenterology 2002;123:227-34.

92. Di Marzo V, Capasso R, Matias I, et al. The role of endocannabinoids in the regulation of gastric emptying: Alterations in mice fed a high-fat diet. Br J Pharmacol 2008;153:1272-80. 


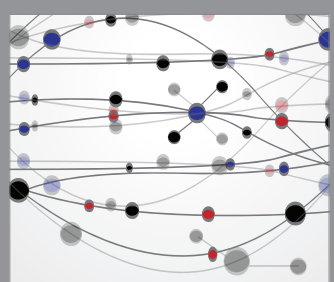

The Scientific World Journal
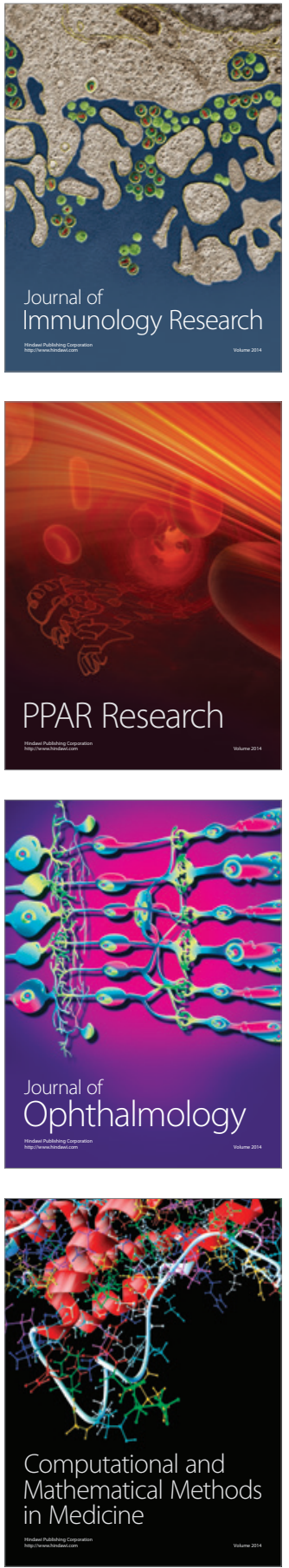

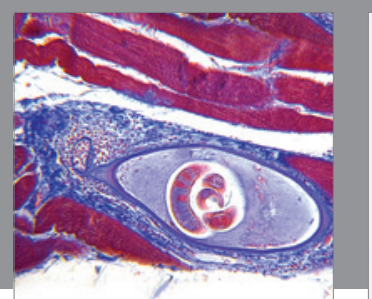

Gastroenterology Research and Practice

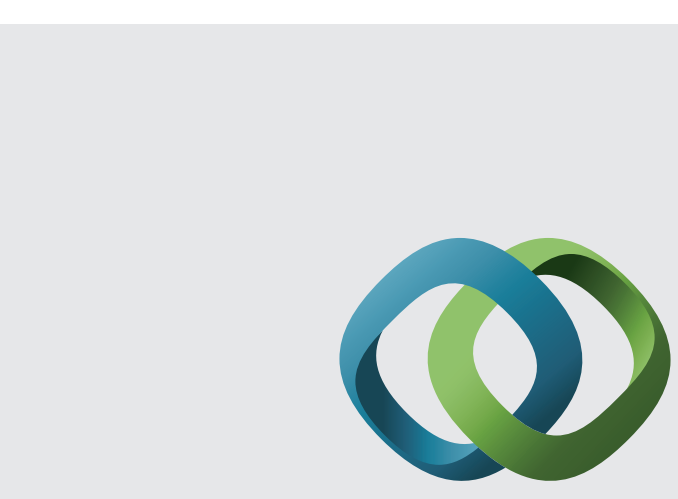

\section{Hindawi}

Submit your manuscripts at

http://www.hindawi.com
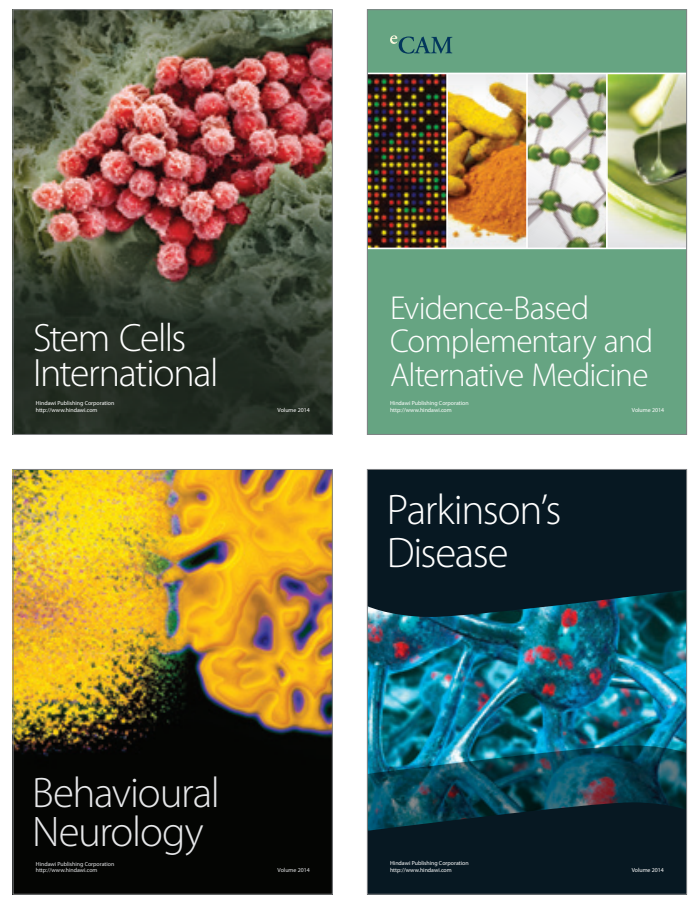
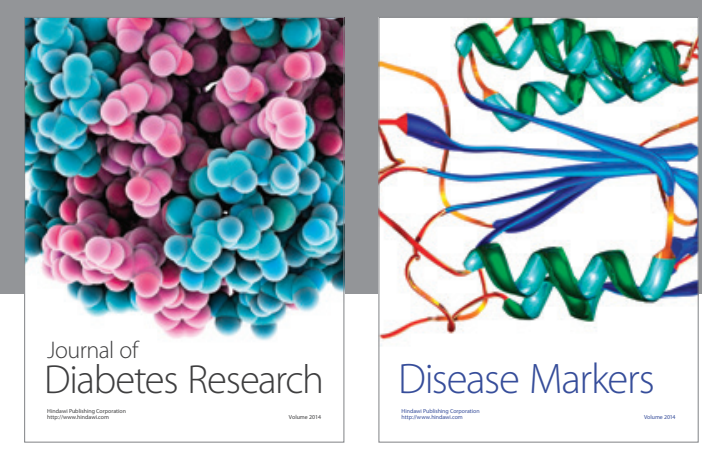

Disease Markers
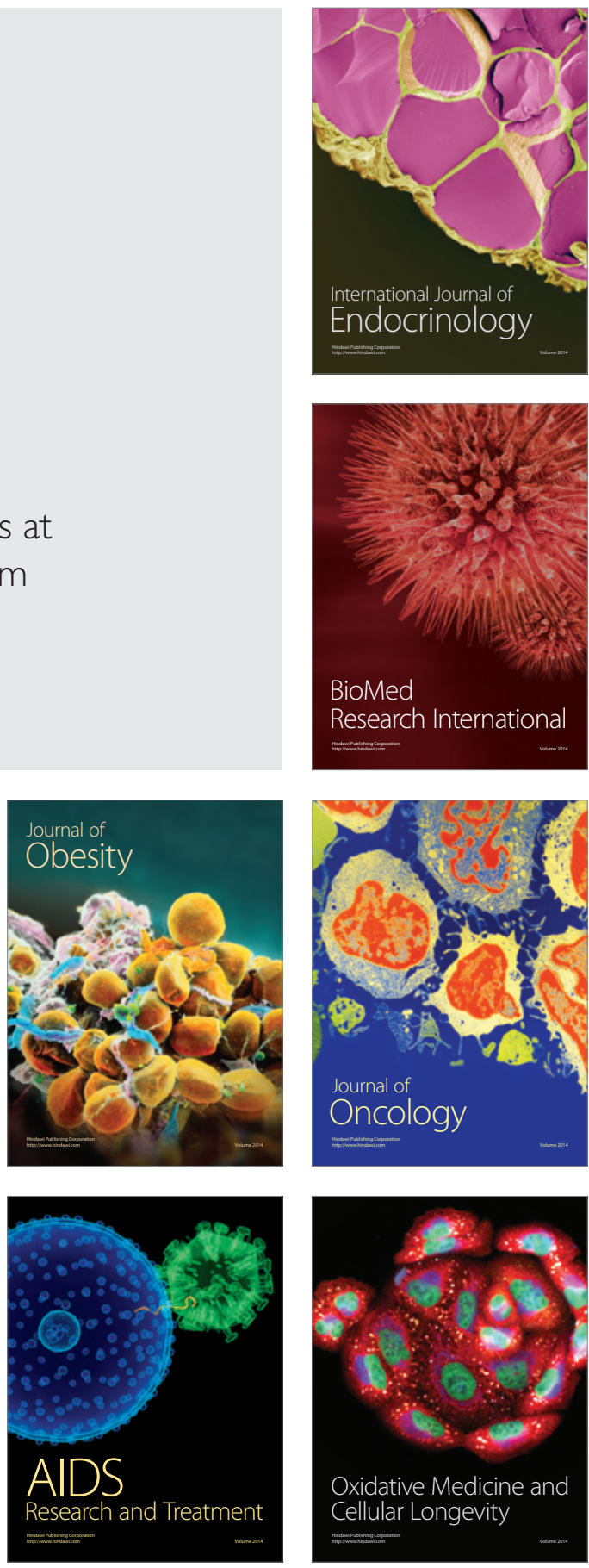